\title{
The evolution of European policies on investment arbitration.
}

\author{
KOTELNIKOV, A.G. and VOROPAEV, K.A.
}

2019

This is the version of record manuscript of the article published by the Ural State Law University in the Herald of the Euro-Asian Law Congress (http://herald.lawcongress.ru/ru/node/2). 
Информация для цитирования:

Котельников А. Г., Воропаев К. А. ЭВОЛЮЦИЯ ЕВРОПЕЙСКОЙ ПОЛИТИКИ

В ОТНОШЕНИИ ИНВЕСТИЦИОННОГО АРБИТРАЖА // Herald of the Euro-Asian Law Congress. 2019. № 1 (3). C. 68-83.

Kotelnikov A., Voropaev K. THE EVOLUTION OF EUROPEAN POLICIES ON INVESTMENT ARBITRATION. Herald of the Euro-Asian Law Congress. 2019. Is. 1 (3). Pp. 68-83.

УДК 347.918

BISAC LAW006000 LAW / Arbitration, Negotiation, Mediation

DOI: 10.34076/2619-0672-2019-1-68-83

\title{
ЭВОЛЮЦИЯ ЕВРОПЕЙСКОЙ ПОЛИТИКИ В ОТНОШЕНИИ ИНВЕСТИЦИОННОГО АРБИТРАЖА
}

\author{
АНДРЕЙ ГЕННАДЬЕВИЧ КОТЕЛЬНИКОВ, \\ Университет Роберта Гордона \\ (Абердин, Великобритания) \\ КОНСТАНТИН АЛЕКСАНДРОВИЧ ВОРОПАЕВ, \\ Р-Фарм (Москва, Россия)
}

Введение: за последние два десятилетия Европейская комиссия радикально изменила свое отношение к инвестиционному арбитражу, став его непримиримым противником. В настоящей статье рассматривается история этих перемен, предпринимается попытка понять прагматическое мышление европейских политиков и оценить достоинства и недостатки предпринятых шагов.

Методы: в статье рассматриваются правовые инструменты, позволившие ЕС осуществить реформу, оценивается их соответствие Вашингтонской конвенции 1965 г. и Договору к Энергетической хартии и анализируется их влияние на инвестиции в Европе. Авторы используют историческую и сравнительно-правовую методологию и в необходимых случаях опираются на статистические данные.

Анализ: причины, лежащие в основе политики ЕС, могли включать в себя недоверие существующей системе инвестиционного арбитража, неудовлетворенность тем, что государствачлены ЕС становились мишенями для инвесторов, стремление продолжить движение Союза в сторону более централизованной федерации и, возможно, популистские мотивы.

Результаты: начав с двусторонних инвестиционных соглашений внутри ЕС, власти ЕС впоследствии возглавили глобальную реформу ISDS с идеей создания постоянных трибуналов, сильно напоминающих государственную судебную систему. Многие по-прежнему настроены скептически, и первоначальные экономические последствия новой политики не были благоприятными. Интересным аспектом реформы оказалась роль, которую пришлось взять на себя Суду Европейского союза. Он нанес решающий удар по существующей системе, реализуя тем самым политику Комиссии, однако не признавая политические мотивы своих решений открыто и опираясь вместо этого на принцип автономии права ЕС.

Ключевые слова: двусторонние инвестиционные соглашения, внутриевропейский инвестиционный арбитраж, разрешение споров между инвестором и государством, арбитраж, МЦУИС, Договор к Энергетической хартии, судебная политика, многосторонний инвестиционный суд 


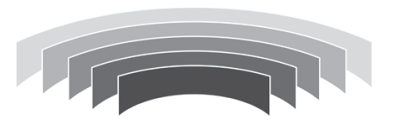

UDC 347.918

BISAC LAW006000

\title{
THE EVOLUTION OF EUROPEAN POLICIES ON INVESTMENT ARBITRATION
}

\author{
ANDREY G. KOTELNIKOV, \\ Robert Gordon University (Aberdeen, United Kingdom) \\ KONSTANTIN A. VOROPAEV, \\ R-Pharm (Moscow, Russia)
}

Introduction: over the last two decades, the European Commission radically altered its attitude towards investment arbitration and became its fierce opponent. This article considers the history of this change, attempts to fathom the pragmatic thinking of the European policy-makers, and considers its wisdom.

Methods: the article analyses legal instruments that allowed the EU to implement the reform, examines their compliance with the Washington Convention 1965 and the Energy Charter Treaty, and considers their effect on investment in Europe. The authors make use of the historical and comparative legal methodology and occasionally rely on statistical data.

Analysis: the reasons behind the EU policies might have included the global backlash against the current system, the dissatisfaction with the Member States being targeted as respondents, the aspirations to move the Union towards a more centralised federation, and possibly the populist motives.

Results: having started with the intra-EU BITs, the EU authorities are now leading the way of the global reform of ISDS with the idea of permanent tribunals bearing a strong resemblance to the state judiciary. Many remain sceptical, and the initial economic effects were unfavourable. A surprising aspect was the role the CJEU had to play. It delivered a decisive blow to the existing system in alignment with the Commission's policies, but without openly admitting the motives behind its decisions, and relying instead on the principle of autonomy of the EU law.

Keywords: bilateral investment treaties, intra-EU investment arbitration, investor-state dispute resolution, arbitration, ICSID, Energy Charter Treaty, judicial politics, multilateral investment court

\section{Introduction}

Since the 1959 Pakistan-Germany bilateral investment treaty (BIT), investor-state arbitration as the legal mechanism safeguarding foreign investments has become a commonplace around the world [Dolzer and Schreuer 2012: 8]. Until the beginning of the twenty-first century, this arbitral paradigm has dominated the thinking about the optimal form of dispute resolution between foreign investors and host states. European governments confidently led the way in negotiating and concluding the new BITs, particularly with the countries outside Western Europe.

Until 2004, there were only two BITs concluded between the European Union countries:
Germany-Greece and Germany-Portugal. Both agreements entered into force prior to Greece and Portugal becoming the EU Member States (1981 and 1986 respectively). The practical result of such a state of affairs was that European investors obtained the guarantees of protection in developing countries, while European governments could feel relatively secure because the reverse flow of investments, from developing countries to Western Europe, was far less significant. Thus, the probability of becoming involved in investment arbitration for the developed states was low. In those early years, the European Commission welcomed and endorsed this form of European international relations [Nyombi and Mortimer 2018: 66]. 
The situation started to change with the new wave of accessions in 2004-2007, when countries such as Bulgaria, Cyprus, Czech Republic, Estonia, Hungary, Latvia, Lithuania, Malta, Poland, Romania Slovakia and Slovenia joined the EU. All of a sudden, instead of merely two, there were more than one hundred and ninety BITs in force between the EU member states [Wehland 2009: 298]. This change of circumstances has coincided with another development on the worldwide scale, namely that the investors and their lawyers finally seemed to realise the potential of arbitrating under the BITs, and the number of claims began to rise dramatically. With those two factors combined, Western European democracies found themselves in a less enviable position.

The global backlash against investor-state dispute resolution [Cotula 2014], exemplified by such events as Russia's withdrawal from the Energy Charter Treaty and the exodus of developing states in Latin America (Venezuela, Bolivia and Ecuador) from the investment protection conventions and institutions in their entirety came as a welcome opportunity from the European regulatory perspective. Having taken over the investment policy from national governments, the European Commission performed a one hundred and eighty degrees turn in its stance on investment arbitration and became its fierce and uncompromising opponent. This move began as a denial of investor-state arbitration within the EU on the basis of intra-EU BITs, but the Commission's aspirations extended beyond that and embraced any investor-state dispute resolution as far as it affected the EU and its Member States.

Against this background, the present article will trace and analyse the range of legal instruments that allowed the EU to implement this change of direction over time, and consider the wisdom of this approach. It will undertake a humble attempt to fathom the pragmatic thinking of the European policy-makers, examine the compliance of this move with the pre-existing legal instruments, in particular, the Washington Convention 1965 and the Energy Charter Treaty (ECT), and consider its practical effects on investment in the European economies. It will also consider briefly the position in which the postBrexit Britain might find itself as a result of these European developments.

\section{Materials and methods}

The author used historical and comparative legal methods.

\section{Results}

The results of the research are expressed in the authors, conclusions.

\section{Discussion}

The current system and the ICSID convention. Investment arbitration, or the Investor-State Dispute Settlement (ISDS) system in its current form, is a procedure for dispute resolution between foreign investors and host states. It relies on an international treaty between two sovereign states (typically, a BIT or a Free Trade Agreement), which provide private parties, the foreign investors, with a right to sue a host state directly in front of an arbitral tribunal that can resolve the dispute and render an enforceable award. Investors can invoke their right to initiate arbitration if they consider that the host state has infringed their substantive rights under the relevant treaty, such as the right to fair and equitable treatment or the guarantees against unlawful expropriation. Apart from the host state's agreement to arbitrate which is given in advance by virtue of its signing of the relevant treaty, many other procedural aspects of investment arbitration resemble closely those of (hitherto) better known commercial arbitration - including the possibility of enforcing the awards under the New York Convention 1958.

The 1965 Convention on the Settlement of Investment Disputes between States and Nationals of other States (the Washington Convention $1965)$ sought to develop this system further. Relying on the host states' consent to arbitrate in BITs or other treaties (the Convention itself does not contain any provisions importing such a consent), it established the International Centre for Settlement of Investment Disputes (ICSID) and laid out the provisions regulating the procedural aspects of investment arbitration. In Art. 52, the Convention set forth the procedure for annulment of an investment arbitration decision. The list of grounds for annulment of an award is restrictive. The Convention does not stipulate the mechanism of ISCID arbitration awards' review on the 


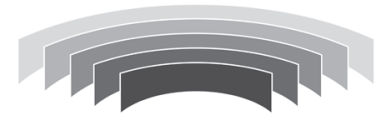

merits, and from the wording of the Convention, it follows that the awards are final and non-appealable.

All the EU member states, with the exception of Poland, are also parties to the Washington Convention 1965. It would appear, therefore, that if an investment arbitration were to take place between the parties to ICSID Convention, even if they were both Member States of the EU, the resulting award would be binding on the parties and not subject to any appeal or to any other remedy (Art. 53 of the Convention). Nonetheless, for the reasons explored below, the European Commission found the system unsatisfactory and sought a way around it.

A host of issues presented themselves when the EU authorities sought to influence the functioning of ICSID arbitration [Kende 2015: 39]. Several legal concepts came into play, including subject matter jurisdiction, res judicata principle, and jurisdictional immunity [Stanivukovic 2014].

One potential issue with the EU moving away from investor-state arbitration within the Union, with the ICSID Convention still in force, is that it might create uncertainty as to the proper forum for the protection of investor rights and, consequently, a new possibility for forum shopping. Vagueness or incoherency of jurisdictional rules has the potential of leading to negative consequences for all participants of legal disputes [McVeigh 2007: 31].

The cumulative result of the recent developments described in greater detail below is that the intra-EU investment arbitration, as far as the Commission is concerned, is no longer possible - neither under the BITs nor under any multilateral treaties such as the ECT. However, the ICSID tribunals continue to disagree and render awards in 'intra-EU' cases. For example, in the recent ICSID award of 31 May 2019 (9REN Holdings SARL v. The Kingdom of Spain, case number $\mathrm{ARB} / 15 / 15)$, the tribunal declared that Spain has violated the fair and equitable treatment standard of the ECT, and awarded a compensation of some $€ 42$ million with costs to the investor incorporated in Luxembourg. In doing so, the tribunal has dismissed Spain's objections concerning the intra-EU investment arbitration.

The following four sections will consider the various methods that the Commission used over time to implement its new policies on investment arbitration.

Early warnings and amicus curiae. The first time when the European Commission made an appearance in an investment arbitration case was back in 2006 when the tribunal in Eastern Sugar B. V. (Netherlands) v. The Czech Republic (SCC case № 088/2004) examined and reproduced in its 2007 Partial Award the Commission's letter to the Czech authorities. At that early stage, the Commission's stance was relatively moderate. It asserted the effective priority of the EU acquis over the inter-EU BITs and said that the prevalence of the EU law was automatic after the date of the Czech Republic's accession to the EU. In Commission's view, the application of intra-EU BITs could lead to the more favourable treatment of investors and investments between the parties covered by the BITs and thus discriminate against the other Member States. However, it also acknowledged that such priority does not lead to automatic invalidity or the impossibility of applying the BIT. The Commission envisaged the need for the relevant Member States to terminate their BITs, indicating that such termination should not have a retroactive effect. Having considered this argument as part of the Respondent's objections, the tribunal disagreed with the Commission and resolved the case on its merits. Thereafter, the Commission intervened as amicus curia on many occasions; below are a few examples.

In 2011, in European American Investment Bank AG (Austria) v. The Slovak Republic (PCA case 2010-17, Award on Jurisdiction of 22 October 2012), the European Commission intervened to submit its observations on the Intra-EU BIT issue. It argued that since the arbitration claims involved questions of application and interpretation of the law covered by the EU treaties, the tribunal had no legal authority to resolve the dispute between the parties. An arbitral tribunal cannot be classified as a court or tribunal of an EU Member State, and arbitrators have no right to request an opinion from the highest judicial body of the EU - the Court of Justice. The tribunal rejected this objection, although it later held that it had no jurisdiction on other grounds.

Likewise, in its 2012 award, the ICSID tribunal had to deal with a similar situation. In Elec- 
trabel SA v. The Republic of Hungary (ICSID case no ARB/07/1), the tribunal allowed the Commission to intervene as an amicus curiae. The Commission argued that the claims of the Belgian energy company could not be considered in international arbitration because the EU law governed the legal matters in dispute. The tribunal eventually disagreed with this interpretation.

In the 2017 ICSID case Eiser Infrastructure Ltd v. Spain (case no ARB/13/36), the Kingdom of Spain enacted legislative measures that promised operators of solar energy units a reimbursement for the produced energy. Later, due to the crisis and tariff deficit, the governmental financial donations stopped. The tribunal held that claimants were deprived of the right to fair and equitable treatment and awarded a compensation to them. Before the merits hearing, the European Commission intervened to submit an amicus $\mathrm{Cu}$ riae brief. Unsurprisingly, the Commission endorsed the position of Spain. The Commission also sought to recover the costs of presenting its submission but the tribunal declined the request.

Thus, by following the ongoing arbitration proceedings for over a decade and intervening as amicus curiae, the Commission demonstrated consistency of legal position but did not achieve any more tangible results. Something else was required to change the prevailing practice. However, it would be hasty to dismiss those efforts as fruitless. At the very least, one thing they accomplished was making sure that the arbitration community was very aware of the existing problem and the EU authorities' stance on the matter.

Enforcement of awards. The other form of influence the European Commission exerted on investment arbitration was resistance to the enforcement of arbitral awards. The New York Convention 1958 provides some legitimate grounds for doing so, notably, the public policy defence (Art. V(2)(b)), the applicability of which may be open to debate in every individual case. However, there are no such grounds in the Washington Convention 1965, Art. 54 of which requires each Contracting State to recognise an award rendered pursuant to the Convention as binding and enforce it in the same manner as a final judgment of a court in that State. Nevertheless, it turned out that there could still be a way to resist the enforcement.
In Micula v. Romania, at least six countries were involved in arbitration procedure and enforcement of the resulting arbitration award. The dispute arose after two Swedish nationals invested in food manufacturing in Romania. Those investments were attributed to the incentives for the development of certain disadvantaged regions, which resulted in tax exemptions. Later, all incentives were withdrawn and the investors started ICSID arbitration against Romania. On the tribunal's request (sic), the Commission intervened to provide an opinion as amicus $\mathrm{cu}$ riae, supporting the host government's position. It argued that resolving the dispute in favour of the claimant would lead to a direct infringement of the EU law. Inter alia, any kind of reimbursement awarded to the claimant would contravene the provision of Art. 107(1) of the Treaty on the Functioning of the European Union (TFEU) that declared any aid granted by a Member State or through State resources distorting or threatening to distort competition incompatible with the internal market. Once again, the tribunal regarded those objections with scepticism.

The arbitrators rendered the award ordering Romania to pay some $\$ 116$ million with interest at the end of 2013. However, on 30 March 2015, the European Commission adopted its own decision declaring the payment of the compensation to be a state aid incompatible with the European single market, and ordering Romania to refrain from paying out any «incompatible aid» to the investors. In Commission's view, the Intra-EU BIT in question (between Sweden and Romania) was contrary to Union law, incompatible with provisions of the Treaties, and therefore invalid. For the same reason, provisions of the ICSID convention did not apply to the present dispute. The Commission did not attach much significance to the fact that most of the events giving rise to the dispute in Micula occurred before Romania's accession to the EU. Remarkably, Romania itself expressed a preference to the ICSID Convention; but the Commission was undeterred. Investors challenged the Commission's findings in the General Court of the EU, the decision of which at the time of writing is pending. In parallel, the award enforcement procedure commenced, involving at various stages the United Kingdom, France, the United States, Belgium, Sweden and Luxembourg. 


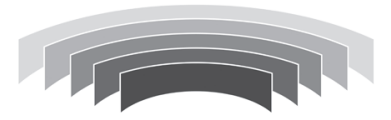

The English High Court in Micula \& others v. Romania [2017] EWHC 31 (Comm) made several important observations on the UK's competing obligations under the ICSID Convention and the EU legislation. The legal battle started with the court issuing a registration order for the award by virtue of Arbitration (International Investment Disputes) Act 1966. Romania, with the European Commission intervening, applied to set aside or stay this order. The court had to decide whether Art. 351 of TFEU was applicable to the present dispute. This Article provides that the provisions of the Treaties shall not affect the rights and obligations arising from agreements concluded before the date of the new Member States' accession to the Union, between one or more Member States on the one hand, and one or more third countries on the other.

Investors argued that the UK had acceded to the ICSID Convention in 1967 while the joining to the EU occurred in 1973, and therefore ICSID rules take priority over any EU provisions, including the European Commission's decision in question, pursuant to Art. 351 of TFEU. Nevertheless, the High Court observed that, since the investors have challenged the Commission's decision, the issue was pending before General Court of the EU, and thus the resolution of the dispute at this point could create a risk of inconsistent judgments. The registration of an award in itself did not infringe the EU law since it merely constituted a proper fulfilment of the UK's obligations under the ICSID Convention. The procedure of award registration does not amount to its enforcement and the latter should comply with the EU legislation. If the Commission prohibited enforcement of a purely domestic English decision, it would be in exactly the same position. Therefore, a stay of enforcement, under those circumstances, did not entail a breach of the UK's ICSID obligations. Art. 4(3) of the Treaty on EU enshrining the obligation of sincere cooperation between the Member States and the provisions of European Communities Act 1972 providing the legal framework for the UK's accession to the EU (and the respective obligation to uphold the previously adopted agreements) were not breached either. This conclusion followed from the risk of noncompliance with the
General Court's decision and the different legal consequences of registration and execution of an award. However, the actual enforcement of the award could presently amount to a breach of the obligation of sincere cooperation. As to whether the Romania-Sweden BIT was valid, the court highlighted that it did not have an authority to consider this issue and the validly of the BIT might be a matter for the Court of Justice of the EU to decide.

Since the enforcement procedure in Europe has come to a halt, the investors and their lawyers turned their attention to the United States. The US Court for the District of Columbia declined the confirmation of an award on an ex parte basis, holding that a proper service on the foreign government under the Foreign Sovereign Immunities Act was required to enforce the ICSID award in the United States. However, the US Court for the Southern District of New York awarded the ex parte affirmation. The defendant lodged an appeal to the US Court of Appeal for the Second Circuit, who vacated the decision of the District Court in October 2017 on the grounds that the lower court's conclusions did not conform to the rules established in Mobil Cerro Negro Ltd et al v. Bolivarian Republic of Venezuela 863 F.3d 96 ( $2^{\text {nd }}$ Cir 2017). The Court of Appeal held that the Foreign Sovereign Immunities Act provided a sole basis for jurisdiction over Romania, and the court lacked jurisdiction under its provisions.

Thus, to a surprise of some in the international arbitration community, the EU authorities were able to stifle, at least for the time being, the enforcement of the ICSID award both within and outside the EU. It is possible that the whole $\mathrm{Mi}$ cula saga was the last straw after which the Commission felt it had to resort to decisive action.

The judicial crusade against intra-EU bits. The landmark dispute that will define the near future of investment arbitration in the EU is Slovak Republic v. Achmea. It involved a company from the Netherlands selling its insurance products in Slovakia. Several years later, the Slovak government amended the national legislation on health insurance prohibiting the distribution of profits from the company's business in the country. After the insurance company obtained compensation in the Germany-seated UNCITRAL 
arbitration, Slovakia challenged the award before the court in Frankfurt. The challenge was unsuccessful at first, and the appeal went all the way to the German Federal Court of Justice. The latter, in turn, requested a ruling by the Court of Justice of the EU (CJEU) as to whether the BIT between the Netherlands and Slovakia was consistent with the EU law.

In its 2018 decision, disagreeing with the opinion of Advocate General Wathelet, the CJEU declared that investment arbitration on the basis of intra-EU BITs was, quite simply, no longer possible. Since the investment arbitral tribunals take account of the domestic law and international agreements of the respondent states, and the EU law forms part of those sets of rules, the tribunals may be required to interpret or apply the EU law. However, such interpretation and application is the domain reserved solely for the EU judicial systems, with the CJEU itself acting as its ultimate custodian. Within the meaning of Art. 267 of TFEU, arbitral tribunals are also not entitled to refer any preliminary questions to the CJEU. Therefore, according to the court, Art. 8 of Netherlands-Slovakia BIT had an «adverse effect on the autonomy of EU law».

If one reads this position literally, the consequences of such finding are far-reaching and by no means limited to intra-EU BITs. Any other similar decision-maker, be it an arbitral tribunal acting on the basis of a BIT with a country outside the EU or an international court of any kind, would have no mandate to apply or interpret the EU law. The court did not specify what exactly such an «application or interpretation» might constitute; apparently, the consideration of the practical effects of an EU measure against the BIT standard easily passed muster.

It is also noteworthy that the CJEU highlighted a special status of investor-state arbitration, distinguishing it from commercial arbitration. The key difference, according to CJEU, was that commercial arbitration procedure relied on the disputing parties willingly submitting to the tribunal's jurisdiction, whereas the investor-state arbitration arose out of an international treaty the effect of which was a re-allocation of domestic jurisdiction. The legal consequence of this kind of removal was the lack of adjudicative remedies which should be in place pursuant to the rules of Art. 19(1) of TFEU.

Achmea will undoubtedly remain in history as one of the least popular CJEU decisions. To date, dozens if not hundreds of articles by academics and practitioners subjected the various aspects of the judgment to severe criticism. For a decision of such momentous impact, it was surprisingly brief, radical, and inconsistent [Barbou des Places, Cimiotta, Vara 2019: 8].

The EU infringement proceedings and political pressure. The fourth form of the influence comprised the European Commission's diplomatic and legal pressure on the Member States outside any a specific dispute. Given that the BITs are a product of a diplomatic effort and a document legally binding on the respective Member States, this may have been the most appropriate channel for communicating and enforcing the new policy. Also, unlike in the individual arbitral cases, this approach had the advantage of investors and lawyers specialising in investor-state dispute resolution having no direct influence on the outcome.

In 2015, the Commission started infringement proceedings against Netherlands, Romania, Slovakia, Austria, and Sweden requesting them to terminate the BITs in force among them [European Commission Press Release 2015]. Having pointed out that the chief goal of BITs was the creation of incentives for foreign investment and improving the business investment environment, the Commission noted two crucial problems that intra-EU BITs create. First, they undermine the EU's single market laws inasmuch as they overlap with them, being inherently incompatible. The second issue follows from the first one and lies in the fact that any pecuniary compensation that an arbitral tribunal may award is in its essence nothing other than illegal state aid.

Those efforts - or perhaps the combination of all four kinds of efforts combined - promise to bring about the change that the Commission advocated from the start. In March 2017, Romania terminated all of its intra-EU BITs on a unilateral basis. After much hesitation and deliberation among the other EU Member States, the breakthrough occurred in January 2019 when all 28 of them signed declarations on the legal con- 


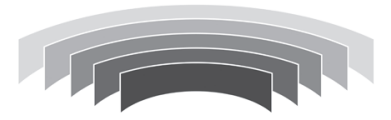

sequences of Achmea and on investment protection in the EU. In those declarations, the countries committed to terminate, bilaterally or plurilaterally, their intra-EU BITs by the end of 2019. Among them, 22 countries declared that Achmea was applicable not only to the BITs but also to the Energy Charter Treaty (ECT). Finland, Luxembourg, Malta, Slovenia and Sweden noted that since the relevant matters were currently pending before the national courts, it would be inappropriate to express views on the compatibility of the ECT with the EU law. Hungary was the only Member State to state expressly that, in its view, Achmea concerned only the intra-EU BITs and did not affect the ECT at all.

The energy charter treaty. The ECT was negotiated and signed in 1994 and entered into force in 1998. Thus, it was another relatively early example of an investment treaty, along with the BITs. Like the BITs, it provided for investor-state arbitration as the primary means of dealing with the foreign investor claims. The distinguishing factor was that, unlike the BITs, it was a multilateral, widely accepted legal instrument promoting uniformity across the region. For our purposes, it is also important to note that the EU was expressly named among the parties of the ECT. Thus, the EU has thereby assumed its own obligations under the investment protection regime and accepted investor-state arbitration as a tool for settling investment disputes [Reinisch 2016: 2].

Although so far the EU has not been involved in an investor-state arbitration pursuant to the rules of the ECT, one could argue that its fate should be different from that of the BITs, and it ought to be exempt from the ambit of Achmea. In its Communication COM/2018/547 of 19 July 2018, the Commission rejected the possibility of such interpretation. It opined that Art. 26 of the ECT, if interpreted correctly as applied to the intra-EU relations, is incompatible with the EU law and thus inapplicable.

The compliance of the ECT dispute resolution provisions with the EU law remains a dividing line between the Member States, as follows from their 2019 declarations, as well as between the European Commission and the ICSID tribunals that continue to decline objections to their jurisdictions based on Achmea. In addition to
9REN Holdings SARL v. The Kingdom of Spain mentioned above, another recent ICSID decision of 7 May 2019 in Eskosol v. Italy (case number ARB/15/50) also refused to admit that Achmea deprived it of jurisdiction to hear a case based on an intra-EU claim under the ECT. As the tribunal pointed out, while the latest positions of the CJEU might make the resulting award unenforceable within the EU, it would remain enforceable elsewhere. Thus, the divide between the ICSID and CJEU jurisprudence on this matter continues to increase.

Investment court: a way forward? Under the 2009 Lisbon Treaty, the Member States have transferred their powers to regulate foreign direct investment to the EU. Thus, the Union must now negotiate the new free trade agreements. In order to be viable, those agreements must envisage a legal protection mechanism as well as the enforcement procedures for investor-state dispute resolution. The new agenda of the Commission for investment disputes could be observed when the EU started to negotiate the new generation of agreements dealing with foreign investment: the Comprehensive Economic and Trade Agreement with Canada (CETA), the EU - Vietnam Free Trade Agreement, etc.

CETA abandons the hitherto conventional approach of investor-state arbitration in favour of a permanent investment tribunal relying on the rules and doctrine akin to those of public judiciary in the Member States of the EU and in Canada. Following the conclusion of CETA negotiations, the Commission released the Recommendation for a Council Decision authorising the opening of negotiations for a Convention establishing a multilateral court for the settlement of investment disputes. It proposed that functions, structure and common aim of this judicial body could rely on the model of permanent investment tribunals established by CETA for the EU-Canada relations [Schacherer 2016: 651].

However, CETA rules themselves are open to criticism. The judges of first and appellate instances are appointed by the CETA Joint Committee comprising the representatives of the contracting parties, i. e. the governments. The investors, should a dispute with a host government arise, cannot select the persons who, from their point of 
view, would be suitable candidates for the resolution of this particular dispute. One could argue that the rules of CETA (Art. 8.27, 8.28 and 8.30) do not aim to provide a mechanism for the establishment of an impartial tribunal independent of both parties, and the principles of selection of the members of this permanent tribunal are quite obscure [Transport \& Environment 2016].

Art. 8.31 of CETA provides that the tribunal may consider the domestic law of a Party «as a matter of fact». In doing so, the tribunal shall follow the prevailing interpretation given to the domestic law by the courts or authorities of that Party and any meaning given to domestic law by the tribunal shall not be binding upon the courts or the authorities of that Party. This article apparently sought to reinforce the principle whereby the CJEU has a monopoly in application and interpretation of the EU law and to preserve the autonomy of the EU legal system. However, that result could only be achieved if CETA made it mandatory for the permanent tribunal to request the CJEU's determination of any issues related to the EU law - which it did not. Thus, following the letter of Achmea, a CETA tribunal is noncompliant with the principle of autonomy of the EU law to the same extent as the investment arbitral tribunals acting under the BITs.

Thus, from an investor's perspective, an investment tribunal model of CETA is not necessarily an attractive alternative to ICSID or UNCITRAL investment tribunals. For the host governments, it also does not represent an unequivocally safe and desirable solution due to the possibility of high monetary compensations that might lead to «regulatory chill» and the tribunal's power to consider the Member States' law and EU measures against standards promulgated by an international treaty.

In European media, both CETA and the EU-US Transatlantic Trade and Investment Partnership (TTIP) had been portrayed as a legal model dictated by the US [Rosenfeld 2016]. Consequently, the proposed model of investor-state dispute resolution was dubbed as «secret courts» or «Trojan horses». [De Binvre, Gstцhl Van Ommeren 2018]. Moreover, CETA's rules were perceived as evidence of the «dark age of nationalism and protectionism» which is coming to the European continent [Lavranos 2018].
Nevertheless, in March 2018, the Council of the EU released negotiating directives for a Convention establishing a multilateral court for the settlement of investment disputes, envisaging that the permanent tribunals under individual investment treaties could eventually be replaced by a single multilateral court. The model those recommendations propose relies on the ideas earlier expressed by the Commission in their criticism of the existing investor-state dispute resolution system.

In 2017, Belgium has requested a CJEU's opinion, inter alia, on the compatibility of the investment tribunal system in CETA with the principle of autonomy of the EU law. The opinion of the Advocate General Bot of January 2019 found no infringement of the EU law, and this time the Court proceeded to fully heed his advice. In its opinion 1/17 of 30 April 2019, CJEU found the envisaged new ISDS system perfectly compatible with the EU legal order.

In many respects, opinion $1 / 17$ apparently sought to rectify some of the damage Achmea brought about. In particular, it has addressed in some detail the threat of a «regulatory chill» that a CETA tribunal jurisdiction might entail. The court emphasised the provisions of CETA stipulating that «except in the rare circumstances when the impact of a measure or series of measures is so severe in light of its purpose that it appears manifestly excessive, non-discriminatory measures of a Party that are designed and applied to protect legitimate public welfare objectives, such as health, safety and the environment, do not constitute indirect expropriations». Indeed, such a public policy exception goes some way in distinguishing this new generation of investment treaties from its predecessors, in light of the experience with some of the more extreme ISDS cases of the recent years, such as Philip Morris or Vattenfall.

However, the CJEU's stance on the principle of autonomy of the EU law remained rather unconvincing. Explaining the distinction it saw between the current situation and that in Achmea, the Court indicated that here, the agreement was between the Union and a non-Member State, rather than between the EU members. Given that Achmea suggested no possibility of such distinction, this argument does not appear very relevant, 


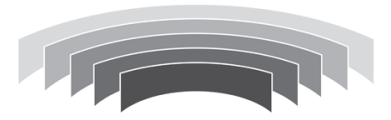

except if understood as a hint to some further considerations on which the Court chose not to elaborate. Second, the CJEU opined that CETA tribunals would be unable to interpret and apply the EU law, unlike the arbitral tribunals under the BITs. This argument draws a distinction between «applying and interpreting» the EU law and treating it «as a matter of fact»; meanwhile, it is far from being clear that the arbitral tribunals ever treated the host States' law as anything other than a matter of fact. Likewise, the Court emphasised that the CETA tribunals' views of the EU law would not be binding on national courts; needless to say, the decisions of investment arbitrators never purported to bind the national courts in this manner, either.

Thus, in its opinion $1 / 17$, the CJEU abandoned its previous orthodoxy as to the meaning of autonomy of the EU law and adopted a more nuanced position. However, it has done so without ever admitting that Achmea was wrongly decided, distinguishing the current case on the grounds that did not quite fit together. One cannot help but feel that the CJEU has treated the all-important principle of autonomy as a mere weapon, a bogeyman that the Court could take out of a cupboard or hide again at will. In this case, CJEU apparently did not feel inclined to condemn the entire system of CETA tribunals. The actual reasons for the court's dislike of investment arbitration and its favourable disposition towards permanent investment tribunals may have remained, once again, largely unarticulated.

In the meantime, the European Commission has submitted its proposals for the reform of ISDS to UNCITRAL, and as of 2019, the discussions about the creation of a new permanent court are underway.

Achmea as a political decision. Given all the legitimate grounds for objection the CJEU's reasoning supplied to its critics in Achmea and did not fully rectify in its CETA opinion $1 / 17$, one is left to wonder if there were perhaps some compelling policy concerns that the Court meant to promote, but which it could not - or chose not to - explain in the text of its judgments.

In fairness, the CJEU often comes under criticism for the quality of its judgments - which, by the UK or US Supreme Courts standards, often leaves much to be desired. This influential court is comprised of judges nominated by each Member State and appointed to six-year renewable terms. Although each judge is required to adjudicate in their personal capacity and not as a representative of their home state, the diversity of their backgrounds and legal training often make it difficult to reach a compromise. Importantly, dissenting opinions are not allowed in the CJEU [Rosenfeld 2006: 635], thus every judge on the panel must agree with the entire text of the judgment. Therefore, the court faces a challenge of writing decisions in a way that would satisfy all its members, often having to delete the controversial paragraphs from the initial draft or making them less direct. Those factors combined result in the CJEU decisions generally being brief and rather stilted.

However, one may doubt if this practical difficulty is sufficient to explain Achmea. Looking for an alternative explanation, the notion of courts being political and furthering their own agendas while resolving individual cases will come as no surprise to any student of judicial decisionmaking. While this is acknowledged as an obvious fact in the US [Sunstein, Schkade, Ellman et al 2007], in other countries, the ideas of judicial independence and separation of powers can make this tendency harder to admit.

As we have seen above, the European Commission spent a long time developing its position on intra-EU arbitration. In addition, the Commission has also been among the most ardent advocates of the ISDS reform generally, whether or not it concerned intra-EU investments. For instance, in its public consultation on ISDS in 2014 and the concept paper in 2015 - as well as in the subsequent communications - the Commission expressed its dissatisfaction with the current system and made proposals for a radical overhaul [Van Harten 2015].

Indeed, along with the Commission, legal scholars have criticised investor-state arbitration on numerous occasions, and its opponents are advancing legitimate arguments. Comparing the legal status of judges and arbitrators in investorstate disputes, several differences immediately present themselves [Waibel, Wu 2017]. The first issue relates to their remuneration. While judges 
earn their salary regardless of the duration of litigation, the volume of evidence or the complexity of the dispute, the fees of investor-state arbitrators depend directly on those considerations. Therefore, arbitrators have a monetary incentive to delay the procedure and make it more complex.

Second, there is the problem of party-appointed arbitrators. It is common for a tribunal to consist of three arbitrators, two of them appointed by each party and the third chosen by the two arbitrators thus appointed. Under such arrangement, there is a risk that appointed arbitrators will feel as if they were representing solely the interests of «their» party, which would be detrimental to neutrality [Waibel, Kaushal, Chung et al. 2010: 203]. In contrast, judges are usually appointed by means of an electronic system or another impartial mechanism, and any kind of interference with its operation is kept to a minimum.

Third, being a judge is a full-time job, and judges cannot be involved in any other commercial activity. Arbitrators routinely engage in multiple arbitration proceedings in different capacities (e. g. as counsel for States or investors) which judges cannot do. This may occasionally lead to a conflict of interests [Laird, Sabahi, Sourgens et al. 2015: 37].

Fourth, decisions of investment tribunals are usually final and binding on parties [Bjorklund 2014: 307]. In contrast, judgments rendered by state courts are appealable on the merits. Judges can be liable to disciplinary proceedings in the event of flagrant violation of procedural or substantive law; arbitrators are selected for the resolution of each particular dispute on a temporary basis, and disciplinary sanctions as such are unavailable in relation to them.

Furthermore, a characteristic of investment arbitration distinguishing it from commercial arbitration is that one of the parties is always the State. This underlines the critical importance of these cases because the stability of relations between the business community and governmental bodies is often at stake here. In the broadest sense, stability lies at the root of favourable investment climate and positive economic outcomes. One essential factor that ensures stability is the uniformity of case law. Because of the confidentiality of arbitration and the absence of a single depo- siting system for awards, it is difficult to ascertain the current legal position on any given issue. Besides, there is no obligation for the investment tribunals to follow the positions adopted by other arbitrators in similar cases [Waibel, Kaushal, Chung et al. 2010: 203]. Conversely, state courts make their judgments publicly available, and commercial parties may rely on them in similar cases - the extent of such reliance depending, of course, on the national legal system in question.

Undoubtedly, proponents of investment arbitration would challenge the validity of each criticism above, often on solid grounds. It would go beyond the ambit of the current paper to express an opinion as to which side of the argument has a better claim to correctness. Instead, it seems more important for our present purposes to suggest that considerations of this kind must have exerted influence on the minds of judges in Achmea and could act as its better explanation than the principle of autonomy. Since none of those considerations was present in the CETA case, the Court may have felt more comfortable dismissing other objections in its opinion 1/17.

Another consideration that the Commission emphasised most strongly, but on which the CJEU failed to elaborate in Achmea, was the functioning of the EU internal market and the potential for creating inequalities between investors from the different Member States. Indeed, if one were to imagine individual US states concluding investment treaties and granting additional privileges to investors from some states but not the others, this would have been close to absurd not to mention manifestly contrary to Art. I of the US Constitution. The EU has been described as something in between a federation and a confederation [Bundzen 2011: 9]. Therefore, such a concern about having an exclusive privilege to regulate investment within the EU signals the EU authorities' determination to continue the development towards a true federation.

Looking at the situation from yet another perspective, various commentators have drawn attention to a recent worldwide tendency of the rising nationalism and populism. For instance, the American 2016 presidential elections and the Brexit vote can be understood as the US and British people's rejection of globalization and a de- 


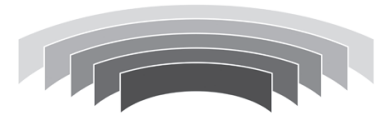

sire to consolidate the policies around national, domestic interests. Similar tendencies and sentiments have been observed in various regions around the world [Davoise, Burgstaller 2018].

Given the close connection between politics and large-scale foreign investment, the legal regulation of investor-state dispute resolution would be unlikely to stay exempt from these influences. One of the crucial arguments against investorstate arbitration is its negative impact on the sovereignty of States. The renegotiation of the North American Free Trade Agreement (NAFTA) and the evolving stance on energy disputes in Mexico both exemplify the growth of nationalistic tendencies in this field [Rovinescu 2018].

Arguably, the policy of the European Commission towards investment arbitration falls squarely into this populist pattern. This is regrettable, because the EU thereby further distances itself from the ideals of democratic inclusion, while also missing out on the opportunities for economic growth. If one were to interpret Achmea as implicitly incorporating those sorts of considerations as well, it would be doubly regrettable, because it would add activism, open support of the executive branch's policies, and lack of transparency on such a crucial matter to the list of grounds for criticism, which is already long enough.

Economic effects of the policy. As shown above, the prospects for investment arbitration in Europe now appear rather gloomy. The model of a permanent judicial body dealing with investment disputes has a built-in bias in favour of the States rather than investors, and it remains to be seen how the investors will react to the new system in the long term.

The position of the EU authorities, at least initially, did not seem to boost investor confidence. The recent outflow of foreign investments from Europe had weakened the EU economic system [Hayes 2016]. In 2017, Foreign Direct Investment (FDI) transferred into the EU from countries outside the EU region was 37 billion euros, which is nearly ten times less than in 2016 (340 billion euros) [Eurostat 2018]. At the sametime, there was a decrease in investments from Europe to overseas countries, which affected most of the EU Member States. The total investment amounted to $20,1 \%$ of GDP in 2017, compared to $22,4 \%$ ten years ago, just prior to the economic and financial crisis. This represents a decrease of 2,3 percentage points [Eurostat 2018 (2)]. Only three countries (Austria, Germany, and Sweden) were able to increase their investment to GDP ratio in 2017 compared to 2007, whereas in Eastern and Southern European countries, the ratio of investment to GDP went down (e. g. in Latvia the decrease was $19,9 \%$, in Greece $13,4 \%$, in Estonia - 12,9 \%). This effect may have been temporary, and, of course, there may have been other reasons responsible for bringing it about; however, it is far from being negligible.

The position of the UK. With its current determination to leave the EU and all the political drama around the terms of this departure, the UK faces unique opportunities as well as unique risks as far as the ISDS system is concerned. The temporary investment outflow referred to above has affected the UK to an even greater extent than the other EU Member States. For example, the Investment Association statistics demonstrated that investors withdrew more than 9 billion pounds since June 2016 when the country voted to leave the EU [Dew 2018].

On the other hand, the UK might be poised to reap some benefits after it exits the EU. If the «no deal» Brexit scenario becomes a reality, it will mean that the EU law would no longer apply in this country. This might, in turn, result in the UK becoming a preferred basis of investment into Europe - close by and protected by the existing BITs yet beyond the reach of Achmea.

Under those conditions, it would be unlikely, for example, that the High Court's stay of proceedings in Micula would remain in place, because it was predicated on the principle of sincere cooperation (Art. 4(3) of the Treaty on European Union) which would cease to apply [Iordache 2019]. In the long term though, such a position might have a detrimental impact on the willingness of European governments to use the London financial industry where their sovereign funds would thereby become liable to the enforcement of arbitral awards by disgruntled investors.

On the other hand, the UK has already signed the most «radical» version of the January 2019 declarations on the legal consequences of 
Achmea and on investment protection in the EU, committing to terminate all of its BITs with the EU Member States. It Britain was to follow through on this commitment and still exit the EU with «no deal»", it would leave the UK investors effectively marooned. They would have lost the conventional BIT protections, but remain unable to benefit from the envisaged new regime that the EU strives to put into place.

\section{Conclusions}

As the above discussion demonstrates, the EU policies on investor-state dispute resolution have changed quite dramatically over the last two decades. Having previously been an ardent supporter of investor-state arbitration, the European Commission has turned into its fierce opponent. There undoubtedly had been a host of policy reasons for this, from the concern about the effect that the current system may have on the EU and Member States' ability to pursue legitimate public policy objectives, to the rather less innocuous populist and nationalist aspirations. Having started with the intra-EU investment arbitration, the Commission did not stop there and is currently leading the way of the worldwide ISDS reform.
One rather surprising aspect of the saga was the apparent inability of the EU executive branch to effect the intra-EU reform solely by diplomatic means. Eventually, it had to be the Court of Justice of the EU that dealt the decisive blow to the existing system. What is more, the Court has done so in perfect alignment with the Commission's policy goals, but without ever admitting it and choosing instead to write at length about a rather vague principle of autonomy of the EU law. The Court was undeterred by the possible conflict of its findings with the Washington Convention 1965 and the Energy Charter Treaty.

Finding out that the EU's highest court feels that it appropriate to support the executive branch's policy despite considerable opposition and without openly acknowledging it is in itself an amusing conclusion. Perhaps such a conclusion would not raise many brows in a developing country, but for the EU it does appear somewhat questionable.

Having faced the initially negative reaction of the investor community, the onus is now on the EU to suggest a better legal framework. Much uncertainty as to the future of ISDS remains - but we might already be starting to see the outlines of the emerging new order.

\section{Список литературы}

Barbou des Places S., Cimiotta E., Santos Vara J. Achmea between the Orthodoxy of the Court of Justice and Its Multi-faceted Implications: An Introduction // European Papers - A Journal on Law and Integration. 2019. Vol. 4. № 1. Pp. 7-19. DOI: https://doi.org/10.15166/2499-8249/297.

Bjorklund A. Yearbook of International Investment Law and Policy 2013-2014. Oxford, 2014. 736 p.

Bundzen A. The United States Supreme Court and the European Court of Justice, A Comparative Study of Compliance. Orebro, 2011. 52 p.

Cotula L. Do Investment Treaties Unduly Constrain Regulatory Space? // Questions of International Law. 2014. Vol. 9. Pp. 19-39.

Davoise M., Burgstaller M. Another One BIT The Dust: Is The Netherlands' Termination Of Intra-EU Treaties The Latest Symptom Of A Backlash Against Investor-State Arbitration? // URL: http://arbitrationblog.kluwerarbitration.com/2018/08/11/another-one-bit-dust-netherlands-termination-intra-eu-treaties-latest-symptombacklash-investor-state-arbitration (accessed 07.06.2019).

De Biuvre D., Gstuhl S., Van Ommeren, E. Overcoming «Frankenfoods» And «Secret Courts»: The Resilience Of EU Trade Policy // College of Europe Policy Brief. 2018. № 9. Pp. 1-6.

Dew L. UK Equity Fund Outflows Soar In May With Almost J10Bn Withdrawn Since Brexit Vote // URL: https://www.investmentweek.co.uk/investment-week/news/3035393/ia-stats-uk-equity-outflows-pass-gbp1bn-in-may-as-investors-seek-protection-from-markets (accessed 07.06.2019).

Dolzer R., Schreuer C. Principles of International Investment Law. Oxford, 2012. 454 p.

Hayes A. Exodus: Record Capital Rushes Out Of Eurozone (Investopedia, 2016) // URL: https://www.investopedia.com/news/exodus-record-capital-rushes-out-eurozone (accessed 07.06.2019). 


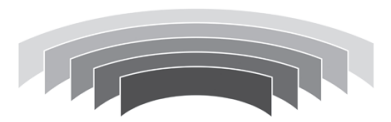

European Commission Press Release. Commission Asks Member States To Terminate Their Intra-EU Bilateral Investment Treaties (18 June 2015) // URL: http://europa.eu/rapid/press-release_IP-15-5198_en.htm (accessed 07.06.2019).

Eurostat. Large Fall In EU Foreign Direct Investment Flows In 2017 (Ec.europa.eu, 2018) // URL: http:// ec.europa.eu/eurostat/web/products-eurostat-news/-/DDN-20180713-1 (accessed 07.06.2019).

Eurostat. How Much Does Your Country Invest? (Ec.europa.eu, 2018) //URL: htttp://ec.europa.eu/eurostat/ web/products-eurostat-news/-/DDN-20180514-1 ?inheritRedirect $=$ true\&redirect $=\% 2$ Feurostat $\% 2$ Ffr $\% 2$ Fhome (accessed 07.06.2019).

Iordache M. Legal Shrapnel: Brexit, Micula and Europe's Banker // URL: http://arbitrationblog.kluwerarbitration.com/2019/04/14/legal-shrapnel-brexit-micula-and-europes-banker (accessed 07.06.2019).

Kende T. Arbitral Awards Classified As State Aid Under European Union Law // ELTE Law Journal. 2015. Vol. 1. Pp. 37-56.

Laird I., Sabahi B., Sourgens F. et al. Investment Treaty Arbitration and International Law. N. Y., 2015. 428 p.

Lavranos N. The CETA Drama: Entering The Dark Age Of Protectionism And Nationalism? // URL: http:// arbitrationblog.kluwerarbitration.com/2016/12/21/the-ceta-drama-entering-the-dark-age-of-protectionism-andnationalism (accessed 07.06.2019).

McVeigh S. Jurisprudence of Jurisdiction. Routledge-Cavendish, 2007. 272 p.

Nyombi C., Mortimer T. The turf war between the European Commission and Intra-EU BITs: is an end in sight // International Arbitration Law Review. 2018. Vol. 21. Pp. 66-79.

Reinisch A. The European Union and investor-state dispute settlement: from investor-state arbitration to a permanent investment court. Waterloo, 2016. 40 p.

Rosenfeld E. Germans: We Hate Obama Trade Plan, But We Don't Hate Americans (CNBC, 2016) // URL: https://www.cnbc.com/2016/09/19/germans-protest-ttip-and-ceta-trade-agreements-with-us-and-canada.html (accessed 07.06.2019).

Rosenfeld M. Comparing constitutional review by the European Court of Justice and the U. S. Supreme Court // International Journal of Constitutional Law 2006. Vol. 4. Pp. 618-651.

Rovinescu L. International Energy Arbitration: Is A New Wave Of «Resource Nationalism» On Its Way? // URL: http://arbitrationblog.kluwerarbitration.com/2018/03/04/5th-annual-joint-conference-internationalenergy-arbitration-new-wave-resource-nationalism-way (accessed 07.06.2019).

Sunstein C., Schkade D., Ellman L., et al. Are Judges Political: An Empirical Analysis of the Federal Judiciary. Washington, 2007. $177 \mathrm{p}$.

Schacherer S. TPP, CETA and TTIP between Innovation and Consolidation-Resolving Investor-State Disputes under Mega-Regionals // Journal of International Dispute Settlement. 2016. Vol. 7. Iss. 3. Pp. 628-653. DOI: https://doi.org/10.1093/jnlids/idw022.

Stanivukovic M. Investment Arbitration: Effects of an Arbitral Award Rendered in a Related Contractual Dispute // Yearbook of International Arbitration. 2014. Vol. 4. Pp. 149-180.

Transport \& Environment. Joint Analysis of CETA'S Investment Court System (ICS) (Transportenvironment. org, 2016) // URL https://www.transportenvironment.org/publications/joint-analysis-ceta\%E2\%80\%99s-investment-court-system-ics (accessed 07.06.2019).

Van Harten G. A Parade of Reforms: The European Commission's Latest Proposal for ISDS // Osgoode Legal Studies Research Paper. 2015. № 21. Vol. 11. Iss. 5. Pp. 1-15.

Waibel M., Kaushal A., Chung K. et al. The Backlash against Investment Arbitration: Perceptions and Reality. Kluwer Law International, 2010. 614 p.

Waibel M., Wu Y. Are Arbitrators Political? Evidence from International Investment Arbitration // ASIL Research Forum Working Paper. 2017. Pp. 1-34.

Wehland H. Intra-EU Investment Agreements and Arbitration: Is European Community Law an Obstacle? // International \& Comparative Law Quarterly. 2009. Vol. 58. Iss. 2. Pp. 297-320. DOI: https://doi.org/10.1017/ S0020589309001067. 


\section{References}

Barbou des Places S., Cimiotta E., Santos Vara J. Achmea between the Orthodoxy of the Court of Justice and Its Multi-faceted Implications: An Introduction, European Papers - A Journal on Law and Integration, 2019, vol. 4, no. 1, pp. 7-19, DOI: https://doi.org/10.15166/2499-8249/297.

Bjorklund A. Yearbook of International Investment Law and Policy 2013-2014, Oxford University Press, 2014, 736 p.

Bundzen A. The United States Supreme Court and the European Court of Justice, A Comparative Study of Compliance, Orebro, 2011, 52 p.

Cotula L. Do Investment Treaties Unduly Constrain Regulatory Space? Questions of International Law, 2014, vol. 9, pp. 19-39.

Davoise M., Burgstaller M. Another One BIT The Dust: Is The Netherlands' Termination Of Intra-EU Treaties The Latest Symptom Of A Backlash Against Investor-State Arbitration? available at: http://arbitrationblog. kluwerarbitration.com/2018/08/11/another-one-bit-dust-netherlands-termination-intra-eu-treaties-latest-symptom-backlash-investor-state-arbitration (accessed 07.06.2019).

De Biuvre D., Gstцhl S., Van Ommeren E. Overcoming «Frankenfoods» And «Secret Courts»: The Resilience Of EU Trade Policy, College of Europe Policy Brief, 2018, no. 9, pp. 1-6.

Dew L. UK Equity Fund Outflows Soar In May With Almost J10Bn Withdrawn Since Brexit Vote, available at: https://www.investmentweek.co.uk/investment-week/news/3035393/ia-stats-uk-equity-outflows-pass-gbp1bnin-may-as-investors-seek-protection-from-markets (accessed 07.06.2019).

Dolzer R., Schreuer C. Principles of International Investment Law, 2nd ed., Oxford, 2012, 454 p.

Hayes A. Exodus: Record Capital Rushes Out Of Eurozone (Investopedia, 2016), available at: https://www. investopedia.com/news/exodus-record-capital-rushes-out-eurozone (accessed 07.06.2019).

European Commission Press Release. Commission Asks Member States To Terminate Their Intra-EU Bilateral Investment Treaties (18 June 2015), available at: http://europa.eu/rapid/press-release_IP-15-5198_en.htm (accessed 07.06.2019).

Eurostat. Large Fall In EU Foreign Direct Investment Flows In 2017 (Ec.europa.eu, 2018), available at: http:// ec.europa.eu/eurostat/web/products-eurostat-news/-/DDN-20180713-1 (accessed 07.06.2019).

Eurostat. How Much Does Your Country Invest? (Ec.europa.eu, 2018), available at: http://ec.europa.eu/eurostat/web/products-eurostat-news/-/DDN-20180514-1 ?inheritRedirect=true\&redirect=\%2Feurostat $\% 2 \mathrm{Ffr} \% 2 \mathrm{Fho}$ me (accessed 07.06.2019).

Iordache M. Legal Shrapnel: Brexit, Micula and Europe's Banker, available at: http://arbitrationblog.kluwerarbitration.com/2019/04/14/legal-shrapnel-brexit-micula-and-europes-banker (accessed 07.06.2019).

Kende T. Arbitral Awards Classified As State Aid Under European Union Law, ELTE Law Journal, 2015, vol. 1, pp. 37-56.

Laird I., Sabahi B., Sourgens F. et al. Investment Treaty Arbitration and International Law, $1^{\text {st }}$ ed., Juris Publishing, 2015, 428 p.

Lavranos N. The CETA Drama: Entering The Dark Age Of Protectionism And Nationalism? available at: http://arbitrationblog.kluwerarbitration.com/2016/12/21/the-ceta-drama-entering-the-dark-age-of-protectionismand-nationalism (accessed 07.06.2019).

McVeigh S. Jurisprudence of Jurisdiction, $1^{\text {st }}$ ed., Routledge-Cavendish, 2007, 272 p.

Nyombi C., Mortimer T. The turf war between the European Commission and Intra-EU BITs: is an end in sight, International Arbitration Law Review, 2018, vol. 21(3), pp. 6-79.

Reinisch A. The European Union and investor-state dispute settlement: from investor-state arbitration to a permanent investment court, Waterloo, 2016, 40 p.

Rosenfeld E. Germans: We Hate Obama Trade Plan, But We Don't Hate Americans (CNBC, 2016), available at: https://www.cnbc.com/2016/09/19/germans-protest-ttip-and-ceta-trade-agreements-with-us-and-canada.html (accessed 07.06.2019).

Rosenfeld M. Comparing constitutional review by the European Court of Justice and the U. S. Supreme Court, International Journal of Constitutional Law, 2006, vol. 4, pp. 618-651. 


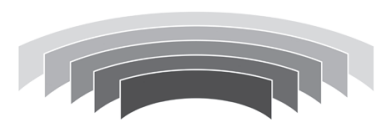

Rovinescu L. International Energy Arbitration: Is A New Wave Of «Resource Nationalism» On Its Way? available at: http://arbitrationblog.kluwerarbitration.com/2018/03/04/5th-annual-joint-conference-internationalenergy-arbitration-new-wave-resource-nationalism-way (accessed 07.06.2019).

Sunstein C., Schkade D., Ellman L. et al. Are Judges Political: An Empirical Analysis of the Federal Judiciary, Washington, 2007, 177 p.

Schacherer S. TPP, CETA and TTIP between Innovation and Consolidation-Resolving Investor-State Disputes under Mega-Regionals, Journal of International Dispute Settlement, 2016, vol. 7, iss. 3, pp. 628-653, DOI: https://doi.org/10.1093/jnlids/idw022.

Stanivukovic, M. Investment Arbitration: Effects of an Arbitral Award Rendered in a Related Contractual Dispute, Yearbook of International Arbitration, 2014, vol. 4, pp. 149-180.

Transport \& Environment. Joint Analysis of CETA'S Investment Court System (ICS) (Transportenvironment. org, 2016), available at: https://www.transportenvironment.org/publications/joint-analysis-ceta\%E2\%80\%99sinvestment-court-system-ics (accessed 07.06.2019).

Van Harten G. A Parade of Reforms: The European Commission's Latest Proposal for ISDS, Osgoode Legal Studies Research Paper, 2015, № 21, vol. 11, iss. 5, pp. 1-15.

Waibel M., Kaushal A., Chung K. et al. The Backlash against Investment Arbitration: Perceptions and Reality, $1^{\text {st }}$ ed., Kluwer Law International, 2010, 614 p.

Waibel M., Wu Y. Are Arbitrators Political? Evidence from International Investment Arbitration // ASIL Research Forum Working Paper, 2017, pp. 1-34.

Wehland H. Intra-EU Investment Agreements and Arbitration: Is European Community Law an Obstacle? International \& Comparative Law Quarterly, 2009, vol. 58, iss. 2, pp. 297-320, DOI: https://doi.org/10.1017/ S0020589309001067.

\section{Информация об авторах}

Андрей Геннадьевич Котельников - кандидат юридических наук, преподаватель Школы права, Университет Роберта Гордона (ул. Гарзди Роад, Абердин, Шотландия, Великобритания AB10 7QE; e-mail: a.kotelnikov@rgu.ac.uk).

Константин Александрович Воропаев - магистр права, член Королевского Института арбитров Великобритании, руководитель отдела комплаенса, Р-Фарм (Ленинский проспект, д. 111В, Москва, Россия 119421; e-mail: kvoropaev90@gmail.com).

\section{Information about the authors}

Andrey G. Kotelnikov - candidate of juridical sciences, lecturer, Law School, Robert Gordon University (Garthdee Road, Aberdeen, AB10 7QE, Scotland, UK; e-mail: a.kotelnikov@rgu.ac.uk).

Konstantin A. Voropaev - LLM, MCIArb, Chief Compliance Office, R-Pharm (111B Leninsky Ave., Moscow, 119421, Russia; e-mail: kvoropaev90@gmail.com).

Дата поступления в редакцию / Received: 22.05.2019

Дата принятия решения об опубликовании / Accepted: 27.08.2019

(ㄷ А. Г. Котельников, 2019 (C) К. А. Воропаев, 2019 